See discussions, stats, and author profiles for this publication at: https://www.researchgate.net/publication/336155330

Intra-Annual Variability in Responses of a Canopy Forming Kelp to

Cumulative Low Tide Heat Stress: Implications for Populations at the Trailing Range Edge

Article in Journal of Phycology · September 2019

DOI: 10.1111/jpy.12927

CITATIONS

5

3 authors:

Hannah F. R. Hereward

Cardiff University

5 PUBLICATIONS 23 CITATIONS

SEE PROFILE

A

Dan A Smale

Marine Biological Association of the UK

123 PUBLICATIONS 7,729 CITATIONS

SEE PROFILE
READS

210

8) Nathan G King

Bangor University

15 PUBLICATIONS 179 CITATIONS

SEE PROFILE

Some of the authors of this publication are also working on these related projects:

Project Examining the ecological consequences of climatedriven shifts in the structure of NE Atlantic kelp forests View project 


\title{
INTRA-ANNUAL VARIABILITY IN RESPONSES OF A CANOPY FORMING KELP TO CUMULATIVE LOW TIDE HEAT STRESS: IMPLICATIONS FOR POPULATIONS AT THE TRAILING RANGE EDGE ${ }^{1}$
}

\author{
Hannah F. R. Hereward \\ Marine Biological Association of the United Kingdom, The Laboratory, Citadel Hill, Plymouth PL1 2PB, UK \\ School of Biological and Marine Sciences, University of Plymouth, Drake Circus, Plymouth PL4 8AA, UK \\ Nathan G. King \\ School of Ocean Sciences, Bangor University, Menai Bridge LL59 5AB, UK \\ and Dan A. Smale ${ }^{2}$ (iD \\ Marine Biological Association of the United Kingdom, The Laboratory, Citadel Hill, Plymouth PL1 2PB, UK
}

\begin{abstract}
Anthropogenic climate change is driving the redistribution of species at a global scale. For marine species, populations at trailing edges often live very close to their upper thermal limits and, as such, poleward range contractions are one of the most pervasive effects of ongoing and predicted warming. However, the mechanics of processes driving such contractions are poorly understood. Here, we examined the response of the habitat forming kelp, Laminaria digitata, to realistic terrestrial heatwave simulations akin to those experienced by intertidal populations persisting at the trailing range edge in the northeast Atlantic (SW England). We conducted experiments in both spring and autumn to determine temporal variability in the effects of heatwaves. In spring, heatwave scenarios caused minimal stress to $L$. digitata but in autumn all scenarios tested resulted in tissue being nonviable by the end of each assay. The effects of heatwave scenarios were only apparent after consecutive exposures, indicating erosion of resilience over time. Monthly field surveys corroborated experimental evidence as the prevalence of bleaching (an indication of physio logical stress and tissue damage) in natural populations was greatest in autumn and early winter. Overall, our data showed that $L$. digitata populations in SW England persist close to their upper physiological limits for emersion stress in autumn. As the intensity of extreme warming events is likely to increase with anthropogenic climate change, thermal conditions experienced during periods of emersion will soon exceed physiological thresholds and will likely induce widespread mortality and consequent changes at the population level.
\end{abstract}

\footnotetext{
${ }^{1}$ Received 18 February 2019. Accepted 11 September 2019

${ }^{2}$ Author for correspondence: e-mail: dansma@mba.ac.uk.

Editorial Responsibility: J. Smith (Associate Editor)
}

Key index words: climate change; Kelp forests; Ocean warming; Species range shifts; Temperate reef communities; Thermal stress

Abbreviations: RWC, relative water content; TW, treatment weight; ENM, environmental niche models

Increased temperature associated with anthropogenic climate change has driven shifts in the distributions of many species as they track optimal thermal habitat (Parmesan et al. 1999, Chen et al. 2011, Poloczanska et al. 2013). While gradual, (mostly) poleward shifts in species' ranges may occur in response to decadal-scale warming trends, short-term extreme warming events can drive rapid stepwise shifts in species' distributions (Jentsch et al. 2007). Discrete extreme warming events (i.e., heatwaves), which are increasing in duration, frequency or intensity in many regions (Coumou and Rahmstorf 2012, Perkins et al. 2012, Oliver et al. 2018), are gaining recognition as forceful agents of ecological change. In terrestrial ecosystems atmospheric heatwaves have caused widespread mortality and consequent range contractions for trees and plant species (Ruthrof et al. 2018). Similarly, in ocean systems, marine heatwaves have decimated populations of seaweeds, invertebrates, fish, and sea birds (Garrabou et al. 2009, Pearce and Feng 2013, Smale and Wernberg 2013, Jones et al. 2018, Smale et al. 2019). However, despite their pervasive nature, a mechanistic understanding of how shortterm warming events drive ecological change is lacking, which limits our ability to better predict the wider ecological consequences of climate change.

While adaptation to local conditions (Sanford and Kelly 2011, Valladares et al. 2014, Bennett et al. 
2015, King et al. 2017a) or heterogeneous patterns of stress intensities (Helmuth et al. 2006, Lourenço et al. 2016) can complicate ecological responses to climatic changes, range-edge populations are generally the most vulnerable to warming (Hampe and Petit 2005, Chen et al. 2011, Smale et al. 2019). At trailing edges, temperatures experienced during heatwaves can often exceed a species' physiological limits, resulting in widespread mortality and stepwise range contractions (Wernberg et al. 2016, Hughes et al. 2017). Moreover, if the species affected by extreme temperatures is an ecologically important foundation species, indirect effects of local extirpation may manifest at the ecosystem level (Thomson et al. 2015, Wernberg et al. 2016). So far, experimental studies have overwhelmingly focused on summer extremes (e.g., Hamerlynck et al. 2000, Van Peer et al. 2004), as this is when any given species' absolute maximum thermal limit is most likely to be exceeded. However, periods of anomalously high temperatures relative to the seasonal climatological average can occur at any time of the year. This may be important as acclimation to lower ambient temperatures during cooler times of year, which could reduce thermal tolerance, is a well-known phenomenon that has been observed in a multitude of taxa (plants - Badger et al. 1982, seaweeds - Lüning 1984, fish - Bulger and Tremaine 1985, crustaceans - Layne et al. 1987, molluscs Chapple et al. 1998, corals - Berkelmans and Willis 1999, insects - Hu and Appel 2004). Therefore, ecological responses to anomalously high temperatures could occur outside of periods of peak ambient temperatures (i.e., summer), but intra-annual variability in responses to realistic extreme warming events have rarely been examined.

Kelps (large brown seaweeds mostly of the order Laminariales) dominate temperate and subpolar rocky reefs and underpin some of the most productive and diverse ecosystems on Earth (Steneck et al. 2002). As their geographic distributions are largely constrained by temperature, kelps are particularly sensitive to warming trends (Eggert 2012). In recent decades both gradual increases in mean temperature (Viejo et al. 2011) and extreme warming events (Smale and Wernberg 2013) have caused high mortality, population declines and local extirpation at trailing edges for several species and in several regions (e.g., Cosson 1999, Raybaud et al. 2013). To date, most studies examining the responses of kelps to warming events, based on either controlled experiments or field observations, have focused on increased seawater temperatures (Wernberg et al. 2013, Reed et al. 2016, Hargrave et al. 2017). However, populations of several kelp species persist at the low intertidal fringe and are exposed to air temperatures multiple times over a spring-neap tidal cycle. Therefore, environmental conditions experienced during periods of emersion can also play a critical role in setting vertical (Flores-Molina et al.
2014, King et al. 2017b) and latitudinal (Martínez et al. 2012, López-Cristoffanini et al. 2013) distributions, and anomalously high air temperatures associated with atmospheric heatwaves could induce physiological stress, mortality and population declines.

We examined the response of the kelp Laminaria digitata to realistic simulations of thermal stress experienced during atmospheric heatwaves occurring over periods of spring low tides. Across the North Atlantic, L. digitata functions as a foundation species on shallow rocky reefs by providing biogenic habitat, altering environmental conditions, and increasing benthic primary production (Schultze et al. 1990). In the northeast Atlantic, it is distributed from the Arctic southwards to its trailing range edge in northwest France, which is characterized by a similar thermal environment to southwest England (the location for the current study). Laminaria digitata has declined in abundance at the trailing range edge in recent decades and much of its southern extent is predicted to disappear by 2100 (Cosson 1999, Raybaud et al. 2013, Smale et al. 2013, Assis et al. 2018). In this region, L. digitata inhabits the low intertidal fringe and, as such, is typically exposed to air temperatures for 1-2 hours, twice a day, for $\sim 4$ consecutive days during periods of spring low tides. We used this as a basis to investigate the effects of realistic heatwave scenarios in both March (i.e., in spring, before annual maximum temperatures) and October (i.e., in autumn, after annual maximum temperatures) to examine temporal variability in responses to extreme warming events.

\section{MATERIALS AND METHODS}

Multiple, mature, medium-sized (stipe length $>20 \mathrm{~cm}$ ) Laminaria digitata sporophytes were haphazardly collected from the low rocky shore at Wringcliff Bay, southwest England, United Kingdom (Fig. 1a), during low tide periods of emersion in both October 2016 and March 2017. Sporophytes were kept in cool, aerated seawater and immediately returned to the laboratory, where they were held in $150 \mathrm{~L}$ tanks for an acclimation period of 7 days. Holding tanks were maintained at ambient sea temperatures $\left(10^{\circ} \mathrm{C}\right.$ in March and $15^{\circ} \mathrm{C}$ in October) using aquarium chillers (DC- 750, Deltec, Delmenhorst). These ambient water temperatures were chosen to reflect actual sea temperatures that natural populations experience during each month (Fig. 1b). Our aim was to simulate realistic conditions with ecological relevance, rather than to repeat the same treatments at two different times. As such, absolute temperatures (both seawater and air) differed between the two experiments whereas the relative intensity of warming treatments were kept consistent (see below). March and October were chosen to represent typical conditions in spring and autumn, respectively. During these seasons, periods of emersion during low spring tides (and therefore exposure to air temperatures) are greatest. Turbulent water flow was generated with a wave maker in each tank (WM-6000, All Pond Solutions, Uxbridge). Salinity was maintained at 35 with the addition of freshwater as necessary; lamps (Reef Daylight T8 $36 \mathrm{~W}$, Interpret, Dorking) 

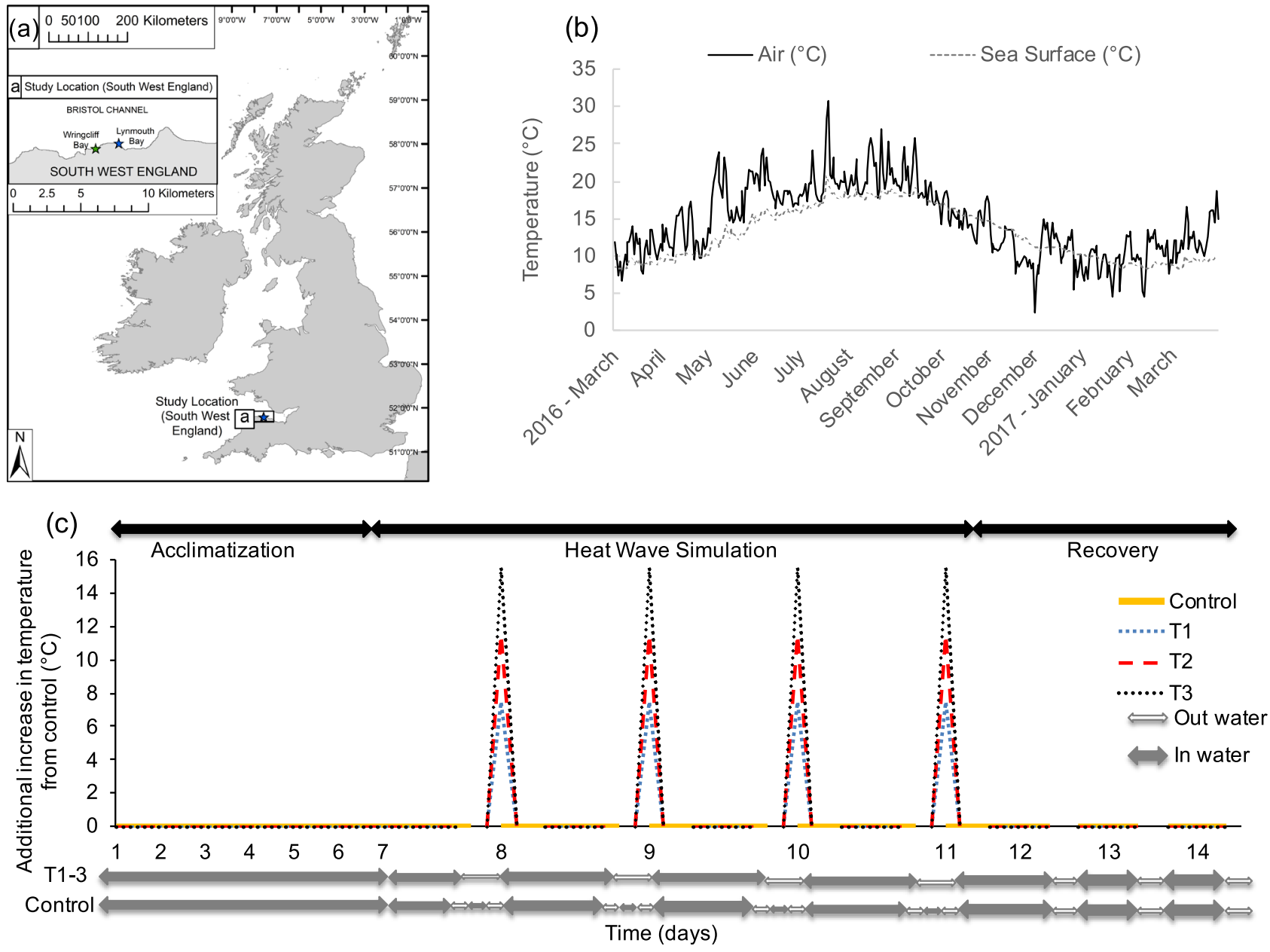

FIG. 1. Study location, climatology, and experimental approach. (a) Map indicates study region and specific location of study sites in North Devon, UK. (b) Maximum air temperature (daily mean temperature 0900-0900) and maximum sea surface temperature within the study region during the experimental period (air temperature data provided by the National Meteorological Library and Archive, Met Office, UK and sea surface temperature data courtesy of Channel Coastal Observatory, England, UK, www.channelcoast.org). (c) Graphical representation of experimental approach used to examine the effect of atmospheric heatwaves on Laminaria digitata. Experiments involved 7 days of acclimatization to seasonally adjusted ambient sea temperatures, followed by 4 days of heatwave simulation and a 3-day recovery period. During the heatwave simulation, Laminaria digitata tissue was consecutively exposed to one of four temperature treatments for $1 \mathrm{~h}$ before being returned to ambient seawater to simulate the returning tide.

specifically designed for aquatic plants were used to generate a 12:12 h light:dark regime with PAR irradiance levels of $\sim 100 \mu \mathrm{mol}$ photons $\cdot \mathrm{m}^{-2} \cdot \mathrm{s}^{-1}$ (recorded with an Odyssey PAR meter). For experimentation, discs of tissue $\left(\right.$ area $8 \mathrm{~cm}^{2}$ ) were excised from epiphyte-free sections of blade tissue found immediately above the meristematic region, using a cork borer. All stress assays described below were performed on individual discs, with responses assumed to reflect that of the wider sporophyte; a well-established approach in phycological research (García-Mendoza and Colombo-Pallotta 2007, Henkel and Hofmann 2008, Pearson et al. 2009, Rothäusler et al. 2009, Jueterbock et al. 2014). Discs were placed in individual sampling pots with holes in the lids to allow free water movement for the duration of the experiment.

From each individual sporophyte four discs were excised, with each being assigned to one of four experimental treatments. Treatments were designed to simulate stress from short-term exposure to air temperatures during periods of low tide emersion, experienced over consecutive days, interspersed with longer periods of immersion in seawater held at typical temperatures. As such, the experiment tested for the effects of consecutive exposures to an atmospheric heatwave, rather than a marine heatwave (sensu Hobday et al. 2016). Treatments involved short-term exposure to one of three air temperatures (Fig. 1c); T1 $\left(7.5^{\circ} \mathrm{C}\right.$ above control), T2 $\left(11.5^{\circ} \mathrm{C}\right.$ above control) and $\mathrm{T} 3\left(15.5^{\circ} \mathrm{C}\right.$ above control), as well as a control set of discs $(\mathrm{C}$; held in seawater except briefly to take measurements described below). The experiments described below were repeated in both March and October, which differ in terms of climatological average temperatures (Fig. 1b). As such, in March the absolute temperatures used were: ambient control $=10.5^{\circ} \mathrm{C}, \quad \mathrm{T} 1=18.0^{\circ} \mathrm{C}, \quad \mathrm{T} 2=22.0^{\circ} \mathrm{C}$ and $\mathrm{T} 3=26.0^{\circ} \mathrm{C}$; whereas in October absolute temperatures were: ambient control $=14.5^{\circ} \mathrm{C}, \quad \mathrm{T} 1=22.0^{\circ} \mathrm{C}, \quad \mathrm{T} 2=26.0^{\circ} \mathrm{C}$ and $\mathrm{T} 3=30.0^{\circ} \mathrm{C}$. Both the absolute and relative increases in temperature were chosen to represent realistic conditions experienced by natural populations in the study region during atmospheric heatwaves (Fig. 1b; Hereward et al. 2018). For example, air temperatures can exceed $20^{\circ} \mathrm{C}$ and $27^{\circ} \mathrm{C}$ in both March and October respectively (Fig. 1b). 
For each treatment, discs were removed from seawater tanks, blotted dry and placed in incubators held at the temperatures described above for one hour, simulating low tide emersion stress ( $n=5$ discs for each treatment). Discs were then returned to seawater tanks for $24 \mathrm{~h}$ to simulate the returning tide. Exposure to the air temperature treatments was repeated for four consecutive days, to simulate emersion patterns during periods of spring low tides. Following 4 days of emersion treatments, a 3-day 'recovery' phase was conducted whereby discs were held in seawater tanks at control temperatures to monitor post-heatwave response patterns. Response variables $\left(F_{v} / F_{m}\right.$ and fresh weight, see below) were measured immediately before and after exposure treatments and once a day during the recovery phase. Stress was measured as maximum quantum yield $\left(F_{v} / F_{m}\right)$ of photosystem II (PSII) using a Pocket PEA chlorophyll fluorimeter (Hansatech Instruments Ltd, Norfolk, UK). The maximum quantum yield of PSII (i.e., the ratio of photochemical quenching, $F_{\mathrm{v}}$, to total fluorescence from closed PSII reaction centers, $F_{\mathrm{m}}$ ) is proportional to its efficiency (Butler 1978). $F_{v} / F_{m}$ is an established method to quantify physiological responses of seaweeds, with a value of $<0.6$ indicative of stress (Pearson et al. 2009, Jueterbock et al. 2014, Saada et al. 2016, King et al. $2017 \mathrm{~b})$. Before all $F_{v} / F_{m}$ measurements were taken, discs were dark adapted for 15 minutes. At the end of the experiment, each disc was photographed, and the area of bleached material quantified using Image J (National Institutes of Health, USA). If the whole disc was no longer a healthy color (i.e., light green) it was scored as $100 \%$ bleached. Discs were then dried $\left(60^{\circ} \mathrm{C}\right.$ for $\left.48 \mathrm{~h}\right)$ to determine the dry weight, from which desiccation rates and relative water content (RWC) were determined using:

$$
\mathrm{RWC}=[(\mathrm{TW}-\mathrm{DW}) /(\mathrm{FW}-\mathrm{DW})] \times 100
$$

where TW is wet weight of treated kelp; FW is initial fresh weight of fully hydrated kelp (pre-treatments); DW is dry weight of kelp disc.

To place experimental results into a wider context, field surveys of natural Laminaria digitata populations were also conducted at two sites in southwest England (Wringcliff Bay and Lynmouth Bay; Fig. 1a). Both sites support dense and extensive stands of $L$. digitata (Hereward et al. 2018). Surveys were conducted each month (i.e., on spring low tides) over a year to quantify levels of in situ bleaching. Ten sporophytes were haphazardly chosen during each survey; bleaching levels were determined using a semiquantitative severity index (Table 1). We developed and used the index as it allowed for rapid nondestructive assessment of bleaching of entire plants. Surveys were conducted at the same tidal height and within a similar area on the shore (fixed using GPS), but different sporophytes were sampled each time to achieve independence.

TABLE 1. Semiquantitative bleaching severity index used to quantify in situ bleaching of mature Laminaria digitata sporophytes at two study sites in North Devon, UK.

\begin{tabular}{ll}
\hline $\begin{array}{l}\text { Level of } \\
\text { bleaching }\end{array}$ & \multicolumn{1}{c}{ Description of bleaching } \\
\hline 0 & No bleaching \\
1 & Tinge - tinges of bleaching \\
2 & $\begin{array}{c}\text { Edge }-<25 \% \text { bleached from edge of some } \\
\text { blade fronds }\end{array}$ \\
3 & $\begin{array}{c}\text { Edge }-\geq 50 \% \text { bleached from edge of some } \\
\text { blade fronds }\end{array}$ \\
4 & Patchy bleaching across whole kelp blade \\
5 & Totally bleached \\
\hline
\end{tabular}

Statistical analysis. As the absolute temperatures used for each treatment varied between months, data from the two experiments were analyzed separately. We formally tested for the effects of Temperature (4 levels: C, T1, T2 and T3) and Time (11 time points) within each experiment, and then informally compared the magnitude of responses between experiments. $F_{v} / F_{m}$ and RWC values were analysed separately using Repeated Measures Analysis of Variance (RM ANOVA) in SPSS v.25 (IBM). Models had two factors: Temperature treatment (4 levels: C, T1, T2 and T3) and Time (11 time points). Residuals were first visually examined to check for normality. Where the assumption of sphericity was violated (Mauchly's test), degrees of freedom were modified with Greenhouse-Geisser corrcetions. Where significant differences were detected, post hoc pair-wise tests were conducted to facilitate interpretation of the RM ANOVA results (t-test with Bonferroni correction). Data on the proportion of discs bleached at the end of the experiments were arcsine transformed and then analysed with a one-way ANOVA with the single factor of Temperature (4 levels: C, T1, T2 and T3).

\section{RESULTS}

In March, the $18^{\circ} \mathrm{C}$ (T1) and $22.0^{\circ} \mathrm{C}$ (T2) treatments had very little effect on $F_{v} / F_{m}$ values, which remained markedly similar to control values before and after each emersion period, as well as during the recovery phase (Fig. 2). The $26.0^{\circ} \mathrm{C}$ (T3) treatment had a notable effect following emersion on Day 3 and Day 4 , but $F_{v} / F_{m}$ values for experimental discs returned to control values during the recovery phase (Fig. 2). In October, however, responses differed markedly, as $F_{v} / F_{m}$ declined sharply after Day 3 of emersion shock in all treatments $\left(\mathrm{T} 1=22.0^{\circ} \mathrm{C}\right.$, $\mathrm{T} 2=26 \cdot 0^{\circ} \mathrm{C}$ and $\left.\mathrm{T} 3=30.0^{\circ} \mathrm{C}\right)$. All the tissue discs failed to recover and $F_{v} / F_{m}$ declined to zero by the end of the experiment in all treatments, indicating that tissue was non-viable (Fig. 2). Statistically, we recorded highly significant effects of all main factors and their respective interactions (Table 2). The 2-way interactions were highly significant in both months, as time effects (i.e., before/after emersion shock, start/end of experiment) varied between temperature treatments but the magnitude of this pattern varied between seasons (Table 3).

In March, all temperature treatments had a notable effect on RWC, which decreased with time, particularly in the $22.0^{\circ} \mathrm{C}$ (T2) and $26.0^{\circ} \mathrm{C}$ (T3) treatments (Fig 3). The consecutive emersion shocks had a marked effect on RWC, with water content dropping to $\sim 60 \%$ and $\sim 40 \%$ in the $22.0^{\circ} \mathrm{C}$ (T2) and $26.0^{\circ} \mathrm{C}$ (T3) treatments, respectively (Fig. 3). Although some recovery was apparent, RWC values did not return to control levels following cumulative shocks (Fig. 3). In October, a similar pattern was observed although the magnitude of impact and decline in RWC was more pronounced in all 3 treatments $\left(\mathrm{T} 1=22.0^{\circ} \mathrm{C}, \mathrm{T} 2=26.0^{\circ} \mathrm{C}\right.$ and $\mathrm{T} 3=30.0^{\circ} \mathrm{C}$; Fig. 3). Statistically, we again recorded highly significant effects of all main factors and their respective interactions (Table 4). The 2-way interactions were indicative of time effects varying 

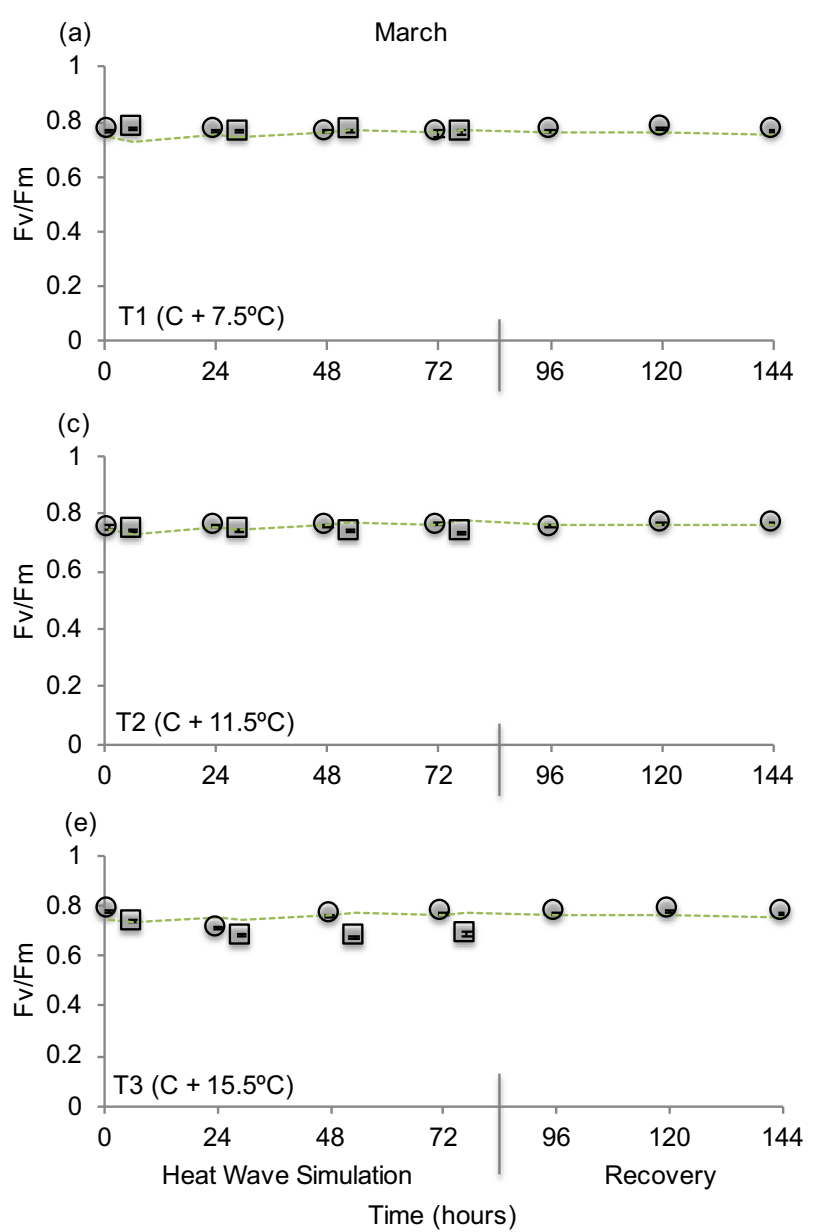

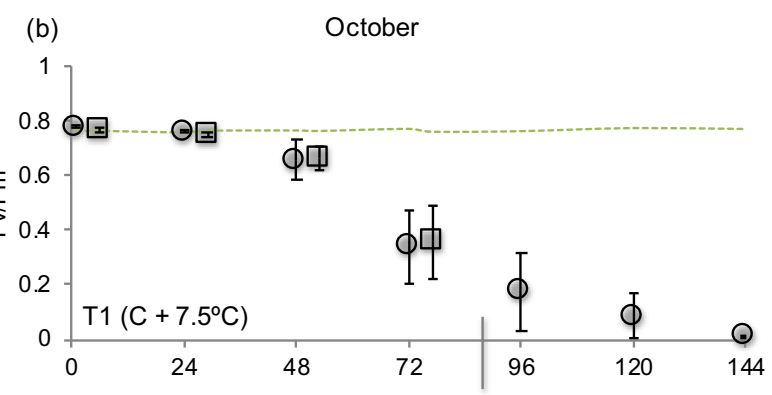

(d)
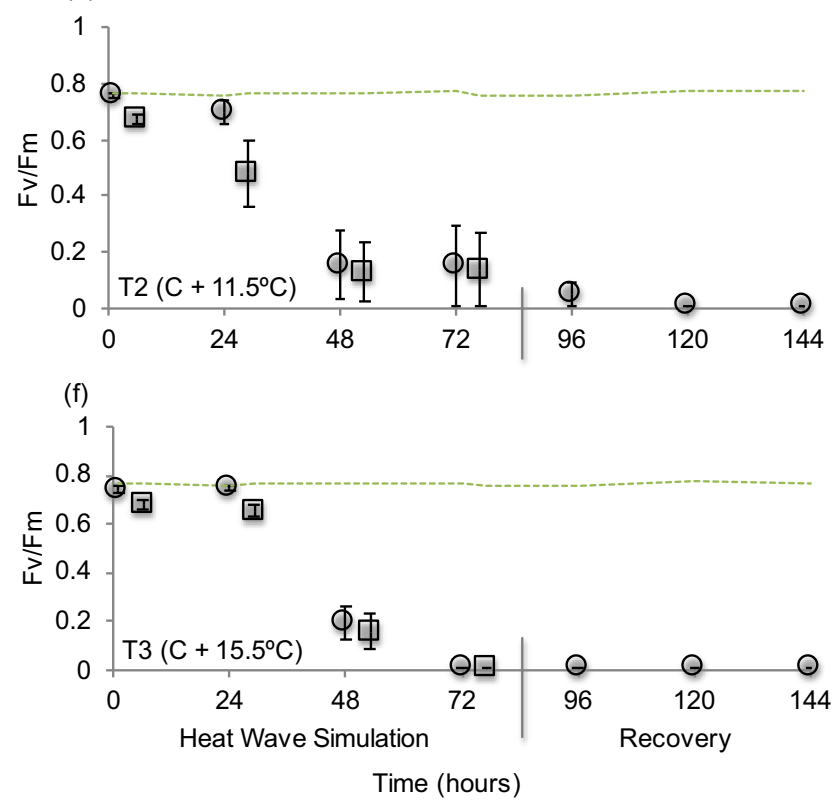

FIG 2. Mean $F_{\mathrm{v}} / F_{\mathrm{m}}$ values $(n=5, \pm \mathrm{SE})$ recorded during spring (left) and autumn (right) experiments, whereby tissue discs were exposed to consecutive $1 \mathrm{~h}$ emersion treatments: $(\mathrm{a}+\mathrm{b}) \mathrm{T} 1$ (control temperature $\left.+7.5^{\circ} \mathrm{C}\right)$, $(\mathrm{c}+\mathrm{d}) \mathrm{T} 2\left(\operatorname{control}\right.$ temperature $+11.5^{\circ} \mathrm{C}$ ) and $(\mathrm{e}+\mathrm{f}) \mathrm{T} 3$ (control temperature $+15.5^{\circ} \mathrm{C}$ ). Square symbols indicate measurements taken immediately after emersion periods. Initial open symbol represents $F_{\mathrm{v}} / F_{\mathrm{m}}$ prior to any experimental treatment. Subsequent open symbols are taken $24 \mathrm{~h}$ after treatments to monitor recovery. Dotted line represents $F_{\mathrm{v}} / F_{\mathrm{m}}$ for controls, which were maintained at ambient temperature.

TABLE 2. Results of a repeated measures ANOVA (with a Greenhouse-Geisser correction for the within-subject effects) to test for differences in $F_{v} / F_{m}$ values in response to consecutive 1 hour emersion heat shocks (C, T1, T2, T3). The model had two factors: Temperature and Time. Significant values $(P<0.05)$ are highlighted in bold.

\begin{tabular}{llrrrrr}
\hline \hline \multicolumn{1}{c}{ Source } & df & SS & MS & F \\
\hline March & Temperature & 3.00 & 0.028 & 0.009 & 41.411 \\
& Time & 3.49 & 0.039 & 0.011 & 49.014 & $<$ \\
\multirow{3}{*}{ October } & Temperature x Time & 10.48 & 0.073 & 0.007 & 30.673 & $<\mathbf{0 . 0 0 1}$ \\
& Temperature & 3.00 & 8.248 & 2.750 & 31.843 & $<\mathbf{0 . 0 0 1}$ \\
& Time & 2.42 & 9.845 & 4.056 & 81.876 & $<\mathbf{0 . 0 0 1}$ \\
& Temperature x Time & 7.28 & 4.633 & 0.636 & $\mathbf{< . 0 0 1}$ \\
\hline
\end{tabular}

between temperature treatments and the magnitude of this pattern varying somewhat between seasons (Table 5). For example, after $24 \mathrm{~h}$ recovery, the RWC of tissue in the October stress treatments did not reach the levels observed at comparable time points in March (Fig. 3).
At the end of the experiment, following the recovery phase, the percentage area of bleaching observed on the tissue discs was highly variable between treatments and between experiments (Fig. 4). In both March and October, we observed a clear effect of temperature treatment, with greater 
TABLE 3. Results of post-hoc pair-wise comparisons between Time points within each Temperature treatment. Comparisons for the March experiment shown in top right of matrix, those for the October experiment in the bottom left. A black circle indicates pair-wise comparisons were significant (at $P<0.01$ ).

\begin{tabular}{|c|c|c|c|c|c|c|c|c|c|c|c|c|}
\hline T1 & March & & & & & & & & & & & \\
\hline \multirow[t]{12}{*}{ October } & & 1 & 2 & 3 & 4 & 5 & 6 & 7 & 8 & 9 & 10 & 11 \\
\hline & 1 & & & & & & & & & & & \\
\hline & 2 & & & & 0 & ○ & 0 & & & & & \\
\hline & 3 & & & & & & & & & & & \\
\hline & 4 & & & & & & & & & & 0 & \\
\hline & 5 & & & & & & & & & & 0 & \\
\hline & 6 & & & & & & & & & & & \\
\hline & 7 & 0 & 0 & 0 & 0 & 0 & 0 & & & & 0 & \\
\hline & 8 & 0 & 0 & 0 & 0 & 0 & 0 & & & & & \\
\hline & 9 & 0 & 0 & 0 & 0 & 0 & 0 & & & & 0 & \\
\hline & 10 & 0 & 0 & 0 & 0 & 0 & 0 & 0 & 0 & & & \\
\hline & 11 & 0 & 0 & 0 & 0 & 0 & 0 & 0 & 0 & & & \\
\hline \multirow{13}{*}{$\begin{array}{l}\text { T2 } \\
\text { October }\end{array}$} & March & & & & & & & & & & & \\
\hline & & 1 & 2 & 3 & 4 & 5 & 6 & 7 & 8 & 9 & 10 & 11 \\
\hline & 1 & & $\bullet$ & & & & 0 & & & & & \\
\hline & 2 & 0 & & 0 & & 0 & & & & 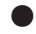 & 0 & 0 \\
\hline & 3 & & & & 0 & & 0 & & 0 & & & \\
\hline & 4 & 0 & 0 & 0 & & 0 & & & & & 0 & 0 \\
\hline & 5 & 0 & 0 & 0 & $\bullet$ & & 0 & & $\bullet$ & & & 0 \\
\hline & 6 & 0 & 0 & 0 & $\bullet$ & & & 0 & & 0 & 0 & 0 \\
\hline & 7 & 0 & ○ & 0 & ○ & & & & 0 & & & \\
\hline & 8 & 0 & 0 & 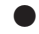 & 0 & & & & & 0 & 0 & 0 \\
\hline & 9 & 0 & 0 & 0 & 0 & & & & & & 0 & 0 \\
\hline & 10 & 0 & 0 & 0 & 0 & & & & & & & 0 \\
\hline & & $\bullet$ & 0 & 0 & $\bullet$ & & & & & & & \\
\hline & March & & & & & & & & & & & \\
\hline \multirow[t]{10}{*}{ October } & & 1 & 2 & 3 & 4 & 5 & 6 & 7 & 8 & 9 & 10 & 11 \\
\hline & 1 & & - & 0 & 0 & 0 & 0 & & 0 & & & \\
\hline & $\begin{array}{l}2 \\
3\end{array}$ & 0 & 0 & 0 & ? & 8 & 8 & $\stackrel{0}{0}$ & ○ & 8 & 8 & 8 \\
\hline & 4 & & & & & 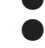 & & 0 & & 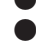 & 0 & 0 \\
\hline & 5 & 0 & 9 & 9 & 9 & & 0 & & 0 & 0 & 0 & 9 \\
\hline & 6 & 0 & 0 & 9 & 0 & & & ○ & & 0 & ○ & ○ \\
\hline & 7 & 0 & 응 & ? & 9 & & & & 0 & & & \\
\hline & $\begin{array}{l}8 \\
9\end{array}$ & $?$ & $?$ & 8 & 8 & & & & & 0 & 0 & 0 \\
\hline & 10 & 0 & 0 & 0 & 0 & & & & & & & 0 \\
\hline & 11 & 0 & 0 & ? & & & & & & & & \\
\hline
\end{tabular}

bleaching observed in the higher intensity treatments (Fig. 4). However, the magnitude of the effect varied between experiments, with high rates of bleaching (up to $100 \%$ in $\mathrm{T} 3,30.0^{\circ} \mathrm{C}$ ) in October compared with moderate bleaching rates $(\sim 50 \%$ in T3, 26. $0^{\circ} \mathrm{C}$ ) in March (Fig. 4). When comparing across the same absolute temperatures (i.e., T3 in March and $\mathrm{T} 2$ in October, both $26^{\circ} \mathrm{C}$ ), bleaching rates were almost double in October compared with March (Fig. 4). Statistically, we recorded a highly significant effect of Temperature treatment in both experiments (one-way ANOVA; March: $F_{3,16}=116.3$, $P<0.001$; October; $\left.\mathrm{F}_{3,16}=58.3, \quad P<0.001\right)$, with post-hoc tests indicating that all treatments differed from one another in both experiments.

The rates of in situ bleaching we observed in natural populations also varied markedly through the year (Fig. 5). At Wringcliff Bay, we recorded negligible bleaching rates in March (in 2016 and 2017), April and May. Similarly, at Lynmouth Bay, minimal bleaching occurred during March (2016 and 2017), May, June, July and August. In contrast, the highest bleaching rates were recorded between October and December at both sites (Fig. 5).

\section{DISCUSSION}

We recorded pronounced variability in the vulnerability of a key habitat-forming kelp to heatwave scenarios between our experiments. The trailing range edge population of Laminaria digitata exhibited little resilience to simulated terrestrial heatwaves in October, whereas ecophysiological responses to similar magnitude warming events in March were minimal. In October, all tissue was non-viable by the end of the experiment, even at the lowest-magnitude treatment tested. This suggests that when autumnal heatwaves coincide with periods of high-magnitude low tides, individuals within natural populations are likely to become highly stressed, exhibiting symptoms of tissue bleaching and necrosis, potentially leading to mortality of the sporophyte. Even if physiological damage was non-lethal, adverse ecophysiological effects could manifest at the individual and 


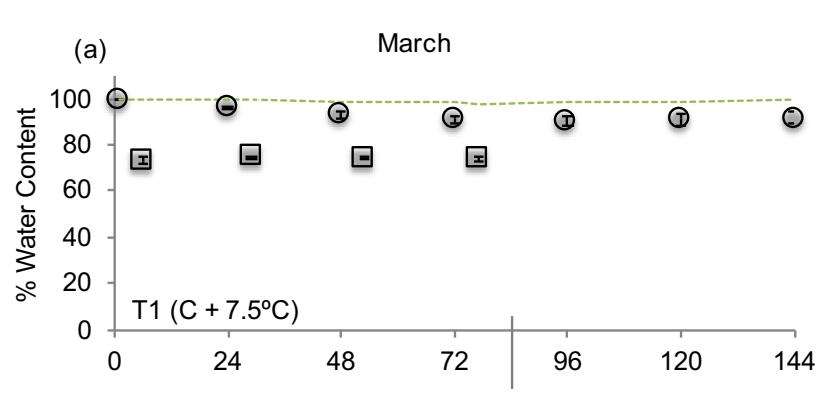

(b)

October

(c)
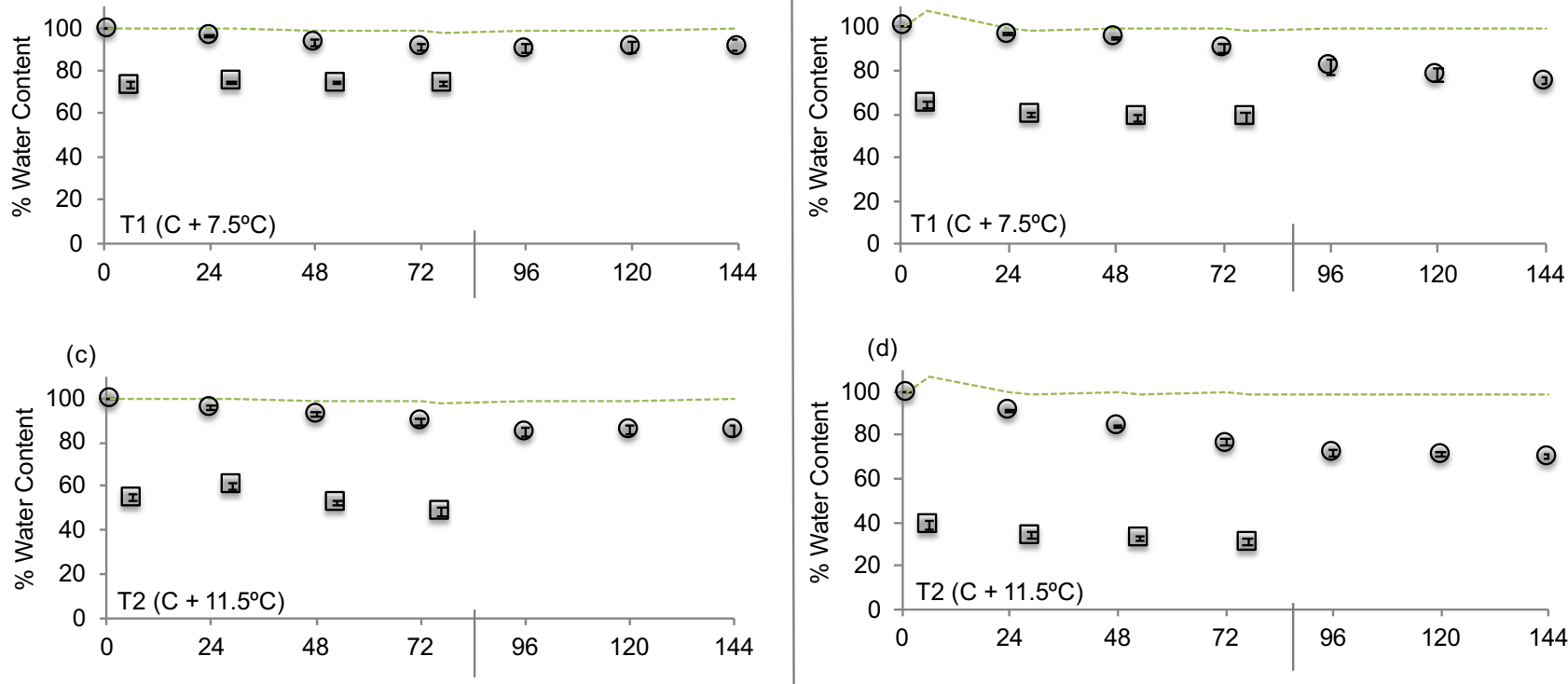

(d)

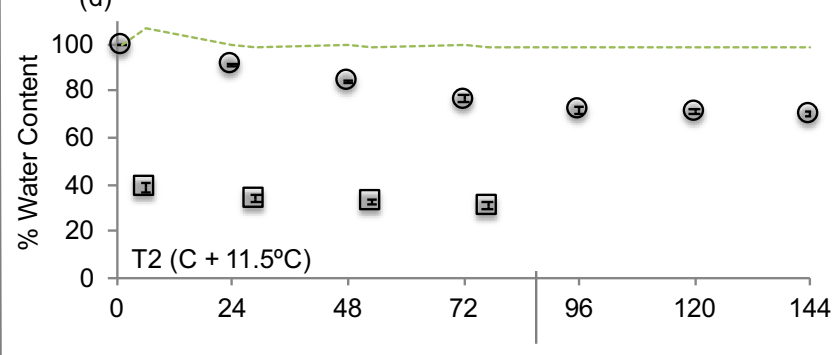

(e)
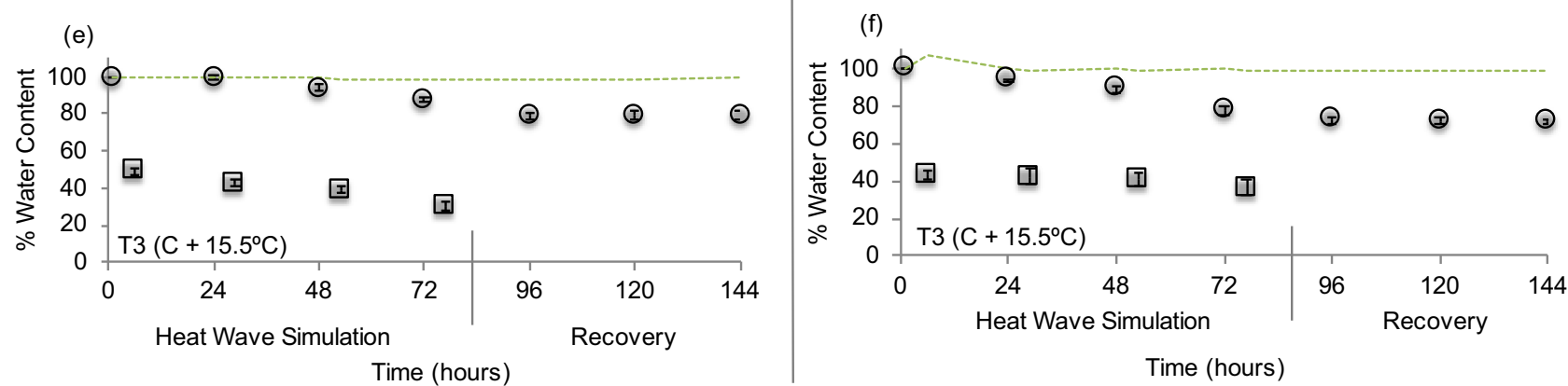

FIG. 3. Mean Relative Water Content (RWC) values $(n=5, \pm \mathrm{SE})$ recorded during spring (left) and autumn (right) experiments, whereby tissue discs were exposed to consecutive $1 \mathrm{~h}$ emersion treatments: $(\mathrm{a}+\mathrm{b}) \mathrm{T} 1$ (control temperature $\left.+7.5^{\circ} \mathrm{C}\right)$, $(\mathrm{c}+\mathrm{d}) \mathrm{T} 2(\mathrm{control}$ temperature $+11.5^{\circ} \mathrm{C}$ ) and $(\mathrm{e}+\mathrm{f}) \mathrm{T} 3$ (control temperature $\left.+15.5^{\circ} \mathrm{C}\right)$. Square symbols indicate measurements taken immediately after emersion periods. Initial open symbol represents RWC prior to any experimental treatment. Subsequent open symbols are taken $24 \mathrm{~h}$ after treatments to monitor recovery.

TABLE 4. Results of a repeated measures ANOVA (with a Greenhouse-Geisser correction for the within-subject effects) to test for differences in relative water content values in response to consecutive 1 hour emersion heat shocks $(\mathrm{C}$, T1, T2, T3). The model had two factors: Temperature and Time. Significant values $(P<0.05)$ are highlighted in bold.

\begin{tabular}{llcrrrr}
\hline \hline \multicolumn{1}{c}{ Source } & df & SS & MS & F & \multicolumn{1}{c}{$P$} \\
\hline March & Temperature & 3.00 & 24682.376 & 8227.459 & 110.307 & $<\mathbf{0 . 0 0 1}$ \\
& Time & 2.17 & 38127.662 & 17544.335 & 713.022 & $<\mathbf{0 . 0 0 1}$ \\
& Temperature x Time & 6.52 & 18834.219 & 2888.837 & 117.406 & $<\mathbf{0 . 0 0 1}$ \\
& Temperature & 3.00 & 43487.540 & 14495.847 & 146.312 & $<\mathbf{0 . 0 0 1}$ \\
& Time & 3.16 & 50700.001 & 16028.348 & 877.288 & $<\mathbf{0 . 0 0 1}$ \\
& Temperature x Time & 9.48 & 20764.694 & 2188.190 & 119.767 & $<\mathbf{0 . 0 0 1}$ \\
\hline
\end{tabular}

population levels. For example, during autumn, actual growth rates of $L$. digitata are low and photosynthetic products are stored as carbohydrates that can be mobilized in the following spring when nutrients become available (Black 1950, Adams et al. 2011). Therefore, sublethal stress caused by bleaching and resource reallocation to cellular repair would restrict capacity to produce and store carbohydrates, with the potential to severely impair productivity and ecological performance (Davison and Pearson 1996).

Our study suggests that Laminaria digitata populations at the trailing range edge are particularly susceptible to autumn heatwaves because: (i) sea temperatures are highest in late summer/autumn (Smyth et al. 2010, Pessarrodona et al. 2018), (ii) air temperatures can exceed $26^{\circ} \mathrm{C}$ (Fig. 1), which was consistently shown to be stressful during our 
TABLE 5. Results of post-hoc pair-wise comparisons between time points within each temperature treatment. Comparisons for the March experiment shown in top right of matrix, those for the October experiment in the bottom left. A black circle indicates pair-wise comparisons were significant (at $P<0.01$ ).

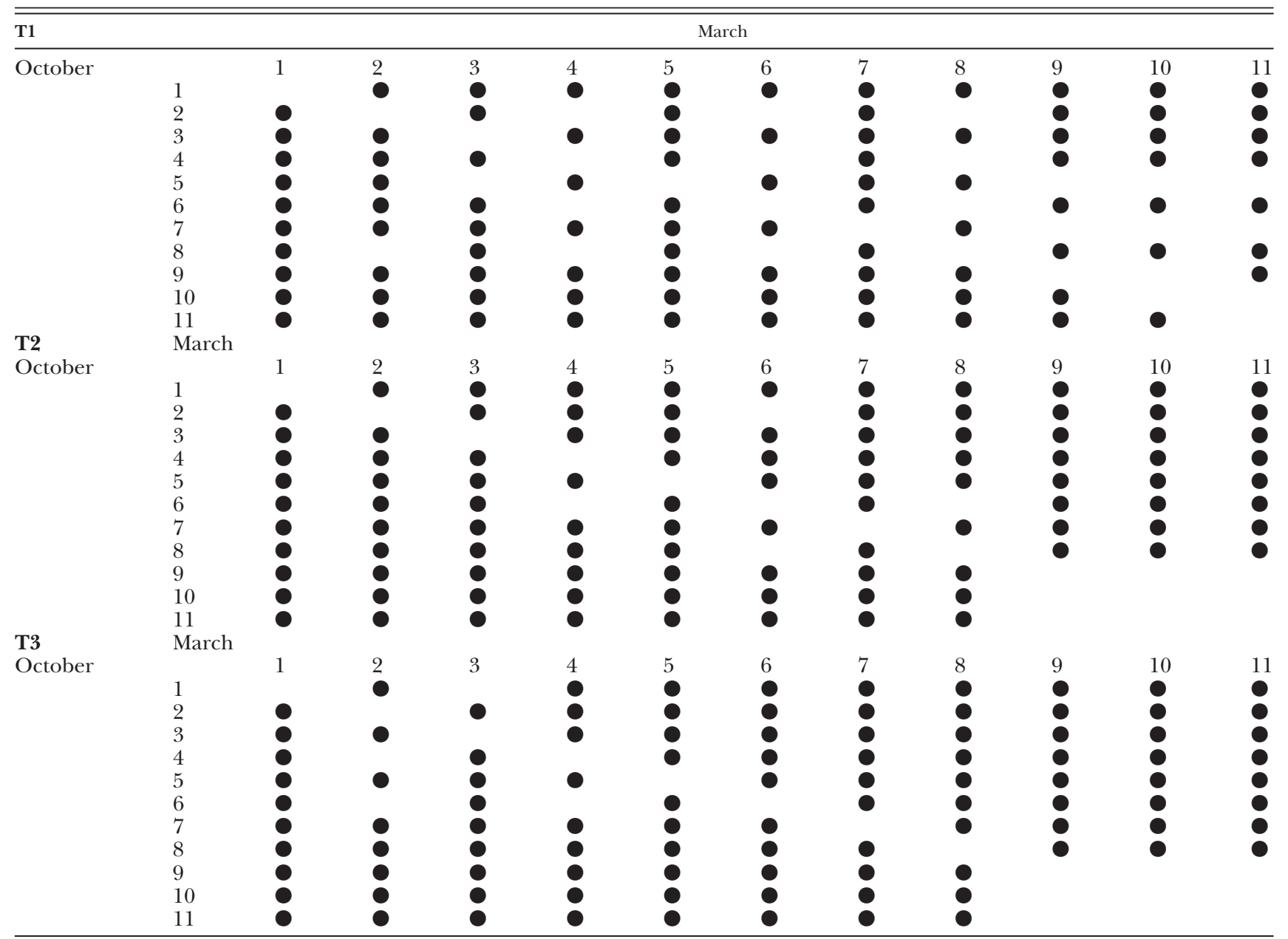

experiments, and (iii) high-magnitude equinox spring tides result in relatively long periods of exposure to air temperatures, thereby increasing the potential for heat and desiccation stress for low shore organisms (Colman 1933). As such, if air temperatures continue to increase or atmospheric heatwaves intensify in autumn, as has been suggested (Coumou et al. 2015, Kendon et al. 2018), L. digitata populations at the trailing edge will be subjected to adverse thermal conditions, with likely consequences for individuals and populations. It should be noted that our ecologically-relevant approach necessitated that different absolute temperature treatments (both seawater and air temperature) were used in March and April, in order to simulate realistic conditions experienced by natural populations. As such, the greater impact and lower recovery observed in October compared with March may have been due to stressful air temperatures, suboptimal water temperatures during the recovery period or an erosion of resilience to thermal stress following a period of chronic high temperatures. Although the relative importance of each mechanism is unclear, the realized combined effects of autumnal heat stress on trailing edge $L$. digitata populations are significant.

Our experimental findings were corroborated by our field surveys of natural populations, as rates of bleaching of blade tissue (indicative of physiological stress) were low in spring/summer and markedly higher in autumn/winter. This increased population-level stress response was likely due to a combination of the chronic effects of high sea temperatures during late summer/autumn, longer periods of emersion stress during spring low tides in autumn and intrinsic biological properties (e.g., lower growth rates in autumn and less replenishment of damaged tissue, Kain 1979, and seasonal variation in biochemistry, Hereward et al. 2018).

Loss of Laminaria digitata at the trailing range edge will perhaps have wider consequences for reef communities along the intertidal fringe, especially 


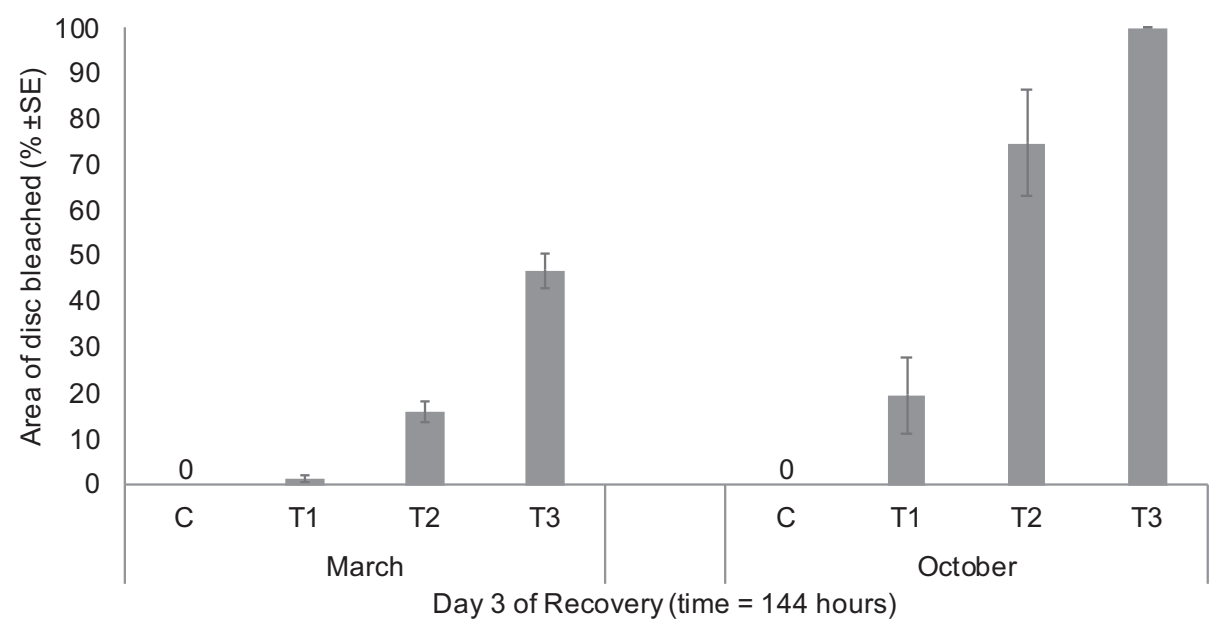

FIG. 4. Mean percentage of bleached tissue $(n=5, \pm \mathrm{SE})$ recorded on Laminaria digitata discs on day three of recovery (the final day of monitoring) following experiments conducted in spring (left) and autumn (right) for each treatment: C (controls held at ambient temperature; T1 (control temperature $\left.+7.5^{\circ} \mathrm{C}\right)$; T2 (control temperature $+11.5^{\circ} \mathrm{C}$ ) and T3 (control temperature $\left.+15.5^{\circ} \mathrm{C}\right)$.

(a) Lynmouth Bay

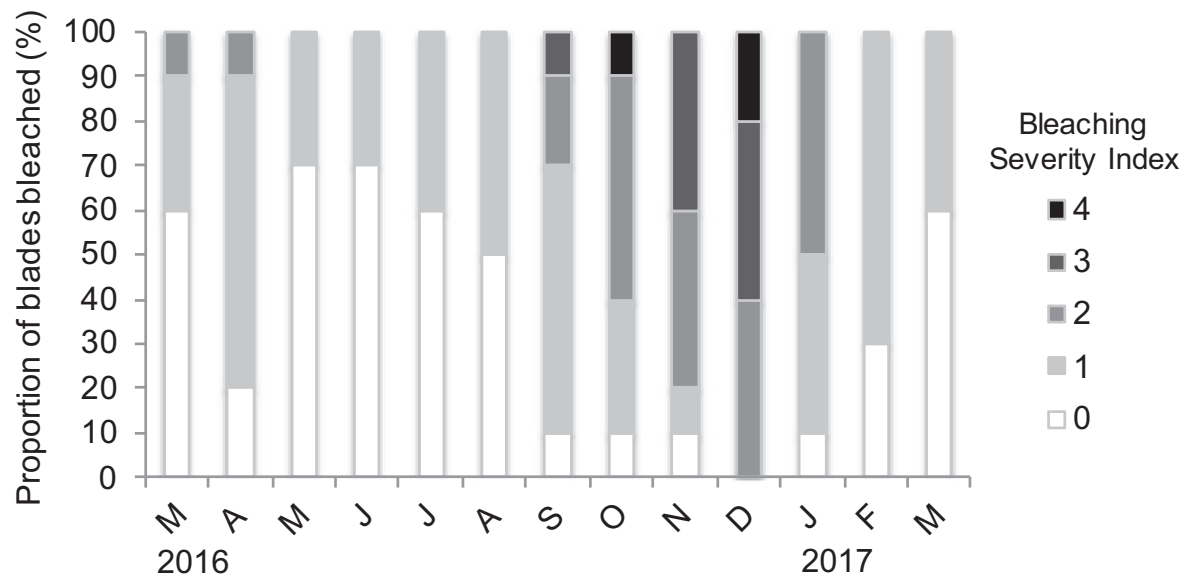

(b) WringcliffBay

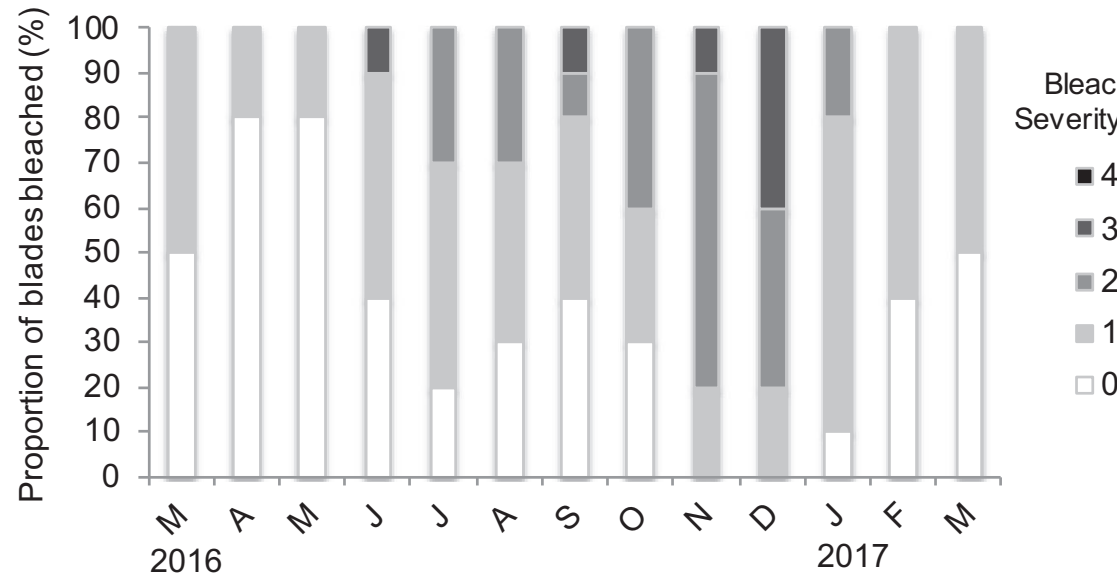

FIg. 5. Level of in situ bleaching observed in natural populations of Laminaria digitata at two sites in North Devon, UK (a $=$ Lynmouth Bay, $\mathrm{b}=$ Wringcliff Bay), across 13 months (March 2016-March 2017). Each month, 10 mature sporophytes were randomly collected and bleaching levels were quantified using a semi-quantitative bleaching severity index described in Table 1. 
as there are no warm-adapted functionally equivalent species to replace it (King et al. 2017b). As a foundation species, $L$. digitata generates habitat for a diverse array of associated flora and fauna (Schultze et al. 1990, Blight and Thompson 2008), provides organic matter for inshore food webs (Schaal et al. 2009) and is an important contributor to overall benthic primary production (Krumhansl and Scheibling 2012). As such, a climate-driven range contraction would likely alter the wider ecological structure and functioning of low intertidal communities in this region.

Trailing edge population losses may also result in the loss of unique genotypic and phenotypic diversity below the species level (e.g., Nicastro et al. 2013). Like many northern hemisphere species, trailing edge populations of seaweeds often acted as refugia during the Quaternary glaciations, and as a result, can harbor the bulk of a species' contemporary genetic diversity (e.g., Assis et al. 2013, Neiva et al. 2016). Trailing edges are also subject to high selective pressures that promote the development of unique phenotypic variation (Kawecki 2008). King et al. (2019) observed reduced genetic diversity but distinct adaptive ecotypes at the trailing edge of Laminaria digitata. Therefore, while climate induced range contractions may not compromise $L$. digitata's genepool the loss of unique phenotypic variation may still threaten the adaptive potential of a species as a whole (Reed and Frankham 2003).

Extreme warming relative to seasonal climatologies can occur year-round, yet intra-annual variability in the impacts of extreme climatic events upon organisms, populations, and communities is poorly understood (De Boeck et al. 2010). Here, heatwave scenarios of a similar relative magnitude in spring had little impact on the ecophysiology of Laminaria digitata, as we observed complete recovery in terms of $F_{v} / F_{m}$ and water content, and only moderate levels of bleaching. This is perhaps counter-intuitive, as seasonal acclimation to lower ambient temperature can lower absolute thermal tolerances (Lüning 1984). This could be explained if thermal set points due to acute stress are more fixed than set points for chronic temperature stress that have generally been employed when measuring thermal tolerance (e.g., Lüning 1984). For example, the heat shock response, which is a key physiological mechanism for dealing with acute thermal stress, has been found to be fixed regardless of incubation temperature (Barua and Heckathorn 2004).

The high vulnerability of Laminaria digitata range edge populations to atmospheric heatwaves in autumn is particularly interesting, as exposure to air temperature is not considered to be a key factor constraining its latitudinal distribution. Unlike most temperate kelps, the peak reproductive period for $L$. digitata occurs in summer, and a major demographic constraint relates to the summer inhibition of gametogenesis (Bartsch et al. 2013). As a result, its latitudinal distribution follows the $17^{\circ} \mathrm{C}$ summer isotherm in sea temperature, which is situated in the Western English Channel. In reality, mature sporophytes are able to grow and survive in sea temperatures far higher than those that natural populations actually experience (Bolton and Luning 1982; N.G. King, unpub. data). However, this does not seem the case for low tide emersion stress, as current climatological conditions are very close to thermal thresholds for $L$. digitata. Therefore, while decadal scale warming may result in a gradual range contraction for $L$. digitata (Raybaud et al. 2013), mediated by inhibition of reproduction, acute stress imposed by exposure to atmospheric heatwaves may invoke more abrupt population declines in the near future.

Our findings highlight some limitations regarding common approaches for measuring stress responses in intertidal organisms. Due to their steep environmental gradients, accessibility and diverse floral and faunal communities, intertidal rocky shores are amongst the world's best-studied ecosystems. In particular, stress physiology has a rich history, with early ecologists attempting to link physiological limits with vertical distributions (e.g., McMahon and Russell-Hunter 1977, Schonbeck and Norton 1978) and more recently to understand future changes in latitudinal distributions (e.g., Harley 2011, King et al. 2017b). However, stress physiology has almost solely focused on critical limits from single exposures, which does not replicate the repeated periods of emersion stress intertidal organisms experience over the course of consecutive spring low tides. King et al. (2017b) found key interspecific differences in thermal tolerance between Laminaria digitata and the congener, L. ochroleuca, which were only revealed through realistic consecutive stress treatments. The current study suggests that consecutive stress exposures are also needed to fully understand responses to atmospheric heatwaves. Assuming that the observed erosion of resilience with consecutive exposures is a common pattern for macroalgae, this means that critical thermal limits have likely been previously underestimated. As Environmental Niche Models (ENMs) move away from correlations with mechanistic cause and effect relationships (Kearney and Porter 2009, Jordà et al. 2012, Sunday et al. 2012, Martínez et al. 2015), identification of accurate physiological limits will become even more critical. Moreover, an accurate understanding of how short-term warming events affect populations will also be critical as ENMs begin to incorporate climatic extremes. As ENMs represent the most widely used tool to predict species redistributions under climate change the incorporation of accurate critical limits will be paramount to increase confidence in projected redistributions.

Understanding species redistributions under climate change is one of the most pressing challenges in contemporary ecology. We have shown 
that populations of an important habitat-forming kelp persist very close to physiological limits for environmental challenges not previously considered. For intertidal organisms, sensitivity to extreme sea temperatures experienced during marine heatwaves needs to be coupled with sensitivity to stressful air temperatures experienced during atmospheric heatwaves. Moreover, it is important to note that these warming trends are not occurring in isolation. Decadal scale gradual warming, marine heatwaves and atmospheric heatwaves constitute different aspects of climate warming, which may interact with each other and with non-climatic stressors (e.g., eutrophication) to erode the resilience of populations and communities in coming decades. To accurately predict future distribution and abundance patterns of intertidal kelp species, such as Laminaria digitata, a deeper mechanistic understanding of these concurrent processes is needed.

We acknowledge A Rocha UK, A Rocha International, and Lee Abbey Devon for supporting the project. Thanks to laboratory technician Angela Ward and assistants Abigail Leach, Sarah Hinkley, and Emma Renshaw. DAS is supported by an Independent Research Fellowship awarded by the Natural Environment Research Council of the UK (NE/K008439/1). We thank RJ Thomas for assistance with statistics and two anonymous reviewers for their constructive comments.

Adams, J. M. M., Toop, T. A., Donnison, I. S. \& Gallagher, J. A. 2011. Seasonal variation in Laminaria digitata and its impact on biochemical conversion routes to biofuels. Bioresour. Technol. 102:9976-84.

Assis, J., Araújo, M. B. \& Serrão, E. A. 2018. Projected climate changes threaten ancient refugia of kelp forests in the North Atlantic. Glob. Change Biol. 24:e55-66.

Assis, J., Coelho, N. C., Alberto, F., Valero, M., Raimondi, P., Reed, D. \& Serrão, E. A. 2013. High and distinct range-edge genetic diversity despite local bottlenecks. PLoS ONE 8: e68646.

Badger, M. R., Björkman, O. \& Armond, P. A. 1982. An analysis of photosynthetic response and adaptation to temperature in higher plants: temperature acclimation in the desert evergreen Nerium oleander L. Plant, Cell Environ. 5:85-99.

Bartsch, I., Vogt, J., Pehlke, C. \& Hanelt, D. 2013. Prevailing sea surface temperatures inhibit summer reproduction of the kelp Laminaria digitata at Helgoland (North Sea). J. Phycol. 49:1061-73.

Barua, D. \& Heckathorn, S. A. 2004. Acclimation of the temperature set-points of the heat-shock response. J. Therm. Biol 29:185-93.

Bennett, S., Wernberg, T., Joy, B. A., De Bettignies, T. \& Campbell, A. H. 2015. Central and rear-edge populations can be equally vulnerable to warming. Nat. Commun. 6:1-7.

Berkelmans, R. \& Willis, B. L. 1999. Seasonal and local spatial patterns in the upper thermal limits of corals on the inshore Central Great Barrier Reef. Coral Reefs 18:219-28.

Black, W. 1950. The seasonal variation in weight and chemical composition of the common British Laminariaceae. J. Mar. Biol. Assoc. U.K. 29:45-72.

Blight, A. J. \& Thompson, R. C. 2008. Epibiont species richness varies between holdfasts of a northern and a southerly distributed kelp species. J. Mar. Biol. Assoc. U.K. 88:469-75.

Bolton, J. J. \& Luning, K. 1982. Optimal growth and maximal survival temperatures of Atlantic Laminaria species (Phaeophyta) in culture. Mar. Biol. 66:89-94.
Bulger, A. J. \& Tremaine, S. C. 1985. Magnitude of seasonal effects on heat tolerance in Fundulus heteroclitus comments. Physiol. Zool. 58:197-204.

Butler, W. L. 1978. Energy distribution in the photochemical apparatus of photosynthesis. Annu. Rev. Plant Physiol. 29:34578.

Chapple, J. P., Smerdon, G. R., Berry, R. J. \& Hawkins, A. J. S. 1998. Seasonal changes in stress-70 protein levels reflect thermal tolerance in the marine bivalve Mytilus edulis L. J. Exp. Mar. Bio. Ecol. 229:53-68.

Chen, I., Hill, J. K., Ohlemuller, R., Roy, D. B. \& Thomas, C. D. 2011. Rapid range shifts of species associated with high levels of climate warming. Science 333:1024-6.

Colman, J. 1933. The nature of the intertidal zonation of plants and animals. J. Mar. Biol. Assoc. U.K. 18:435-76.

Cosson, J. 1999. Sur la disparition progressive de Laminaria digitata sur les côtes du Calvados (France). Cryptogam. Algol. 20:35-42.

Coumou, D., Lehmann, J. \& Beckmann, J. 2015. The weakening summer circulation in the Northern Hemisphere mid-latitudes. Science 348:324-7.

Coumou, D. \& Rahmstorf, S. 2012. A decade of weather extremes. Nat. Clim. Chang. 2:491-6.Davison, I.R. \& Pearson, G.A. 1996. Stress tolerance in intertidal seaweeds. J. Phycol. 32:197-211.

De Boeck, H. J., Dreesen, F. E., Janssens, I. A. \& Nijs, I. 2010. Climatic characteristics of heat waves and their simulation in plant experiments. Glob. Change. Biol. 16:1992-2000.

Davison, I. R. \& Pearson, G. A. 1996. STRESS TOLERANCE IN INTERTIDAL SEAWEEDS. Journal of Phycology 32:197-211.

Eggert, A. 2012. Seaweed responses to temperature. In Wienche, C. \& Bischof, K. [Eds.] Seaweed Biology. Springer-Verlag, Berlin, Germany, pp 47-66.

Flores-Molina, M. A., Thomas, D., Lovazzano, C., Nunez, A., Zapata, J., Kumar, M., Correa, J. A. \& Contreras-Porcia, L. 2014. Desiccation stress in intertidal seaweeds: effects on morphology, antioxidant responses and photosynthetic performance. Aquat. Bot. 113:90-9.

García-Mendoza, E. \& Colombo-Pallotta, M. F. 2007. The giant kelp Macrocystis pyrifera presents a different nonphotochemical quenching control than higher plants. New Phytol. 173:526-36.

Garrabou, J., Coma, R., Bensoussan, N., Bally, M., Chevaldonné, P., Cigliano, M., Diaz, D. et al. 2009. Mass mortality in Northwestern Mediterranean rocky benthic communities: effects of the 2003 heat wave. Glob. Change Biol. 15:1090-103.

Hamerlynck, E. P., Huxman, T. E., Loik, M. E. \& Smith, S. D. 2000. Effects of extreme high temperature, drought and elevated $\mathrm{CO}_{2}$ on photosynthesis of the Mojave Desert evergreen shrub, Larrea Tridentata. Plant Ecol. 148:183-93.

Hampe, A. \& Petit, R. J. 2005. Conserving biodiversity under climate change: the rear edge matters. Ecol. Lett. 8:461-7.

Hargrave, M. S., Foggo, A., Pessarrodona, A. \& Smale, D. A. 2017. The effects of warming on the ecophysiology of two co-existing kelp species with contrasting distributions. Oecologia 183:531-43.

Harley, C. D. G. 2011. Climate change, keystone predation, and biodiversity loss. Science 334:1124-7.

Helmuth, B., Mieszkowska, N., Moore, P. \& Hawkins, S. J. 2006. Living on the edge of two worlds: changing the responses forecasting intertidal of rocky to climate ecosystems change. Annu. Rev. Ecol. Syst. 37:373-404.

Henkel, S. K. \& Hofmann, G. E. 2008. Differing patterns of hsp70 gene expression in invasive and native kelp species: evidence for acclimation-induced variation. J. Appl. Phycol. 20:915-24.

Hereward, H. R. F., Foggo, A., Hinckley, S. L., Greenwood, J. \& Smale, D. A. 2018. Seasonal variability in the population structure of a habitat-forming kelp and a conspicuous gastropod grazer: do blue-rayed limpets (Patella pellucida) exert top-down pressure on Laminaria digitata populations? J. Exp. Mar. Biol. Ecol. 506:171-81. 
Hobday, A. J., Alexander, L. V., Perkins, S. E., Smale, D. A., Straub, S. C., Oliver, E. C. J., Benthuysen, J. A. et al. 2016. A hierarchical approach to defining marine heatwaves. Prog. Oceanogr. 141:227-38.

Hu, X. P. \& Appel, A. G. 2004. Seasonal variation of critical thermal limits and temperature tolerance in Formosan and eastern subterranean termites (Isoptera: Rhinotermitidae). Environ. Entomol. 33:197-205.

Hughes, T. P., Kerry, J. T., Álvarez-Noriega, M., Álvarez-Romero, J. G., Anderson, K. D., Baird, A. H., Babcock, R. C. et al. 2017. Global warming and recurrent mass bleaching of corals. Nature 543:373-7.

Jentsch, A., Kreyling, J. \& Beierkuhnlein, C. 2007. A new generation of climate change experiments: events, not trends. Front. Ecol. Environ. 5:365-74.

Jones, T., Parrish, J. K., Peterson, W. T., Bjorkstedt, E. P., Bond, N. A., Ballance, L. T., Bowes, V. et al. 2018. Massive mortality of a planktivorous seabird in response to a marine heatwave. Geophys. Res. Lett. 45:3193-202.

Jordà, G., Marbà, N. \& Duarte, C. M. 2012. Mediterranean seagrass vulnerable to regional climate warming. Nat. Clim. Chang. 2:821-4.

Jueterbock, A., Kollias, S., Smolina, I., Fernandes, J. M. O., Coyer, J. A., Olsen, J. L. \& Hoarau, G. 2014. Thermal stress resistance of the brown alga Fucus serratus along the North-Atlantic coast: acclimatization potential to climate change. Mar. Genomics 13:27-36.

Kain, J. M. 1979. A view of the genus Laminaria. Oceanogr. Mar. Biol. Ann. Rev. 17:101-61.

Kawecki, T. J. 2008. Adaptation to marginal habitats. Ann. Rev. Ecol. Evol. Syst. 39:321-42.

Kearney, M. \& Porter, W. 2009. Mechanistic niche modelling: combining physiological and spatial data to predict species' ranges. Ecol. Lett. 12:334-50.

Kendon, M., McCarthy, M., Jevrejeva, S., Matthews, A. \& Legg, T. 2018. State of the UK climate 2017. Int. J. Climatol. 38:1-35.

King, N. G., McKeown, N. J., Smale, D. A. \& Moore, P. J. 2017 a. The importance of phenotypic plasticity and local adaptation in driving intraspecific variation variability in thermal niches of marine macrophytes. Ecography 40:001-14.

King, N. G., McKeown, N. J., Smale, D. A., Wilcockson, D. C., Hoelters, L., Groves, E. A., Stamp, T. \& Moore, P. J. 2019. Evidence for different thermal ecotypes in range centre and trailing edge kelp populations. J. Exp. Mar. Bio. Ecol. 515:107.

King, N. G., Wilcockson, D. C., Webster, R., Smale, D. A., Hoelters, L. S. \& Moore, P. J. 2017b. Cumulative stress restricts niche filling potential of habitat-forming kelps in a future climate. Funct. Ecol. 32:288-99.

Krumhansl, K. \& Scheibling, R. 2012. Production and fate of kelp detritus. Mar. Ecol. Prog. Ser. 467:281-302.

Layne, J. J. R., Claussen, D. L. \& Manis, M. L. 1987. Effects of acclimation temperature, season, and time of day on the critical. J. Therm. Biol 12:183-7.

López-Cristoffanini, C., Tellier, F., Otaíza, R., Correa, J. A. \& Contreras-Porcia, L. 2013. Tolerance to air exposure: a feature driving the latitudinal distribution of two sibling kelp species. Bot. Mar. 56:431-40.

Lourenço, C. R., Zardi, G. I., McQuaid, C. D., Serrão, E. A., Pearson, G. A., Jacinto, R. \& Nicastro, K. R. 2016. Upwelling areas as climate change refugia for the distribution and genetic diversity of a marine macroalga. J. Biogeogr. 43:1595607.

Lüning, K. 1984. Temperature tolerance and biogeography of seaweeds: the marine algal flora of Helgoland (North Sea) as an example. Helgolander Meeresuntersuchungen 38:305-17.

Martínez, B., Arenas, F., Rubal, M., Burgués, S., Esteban, R., García-Plazaola, I., Figueroa, F. L. et al. 2012. Physical factors driving intertidal macroalgae distribution: physiological stress of a dominant fucoid at its southern limit. Oecologia 170:34153.

Martínez, B., Arenas, F., Trilla, A., Viejo, R. M. \& Carreño, F. 2015. Combining physiological threshold knowledge to species distribution models is key to improving forecasts of the future niche for macroalgae. Glob. Change Biol. 21:142233.

McMahon, R. F. \& Russell-Hunter, W. D. 1977. Temperature relations of aerial and aquatic respiration in six littoral snails in relation to their vertical zonation. Biol. Bull. 152:182-98.

Neiva, J., Serrão, E. A., Assis, J., Pearson, G. A., Coyer, J. A., Olsen, J. L., Hoarau, G. \& Valero, M. 2016. Climate oscillations, range shifts and phylogeographic patterns of North Atlantic Fucaceae. In. Hu, ZM. \& Fraser, C. Seaweed Phylogeography. Springer, Netherlands, pp 279-308.

Nicastro, K. R., Zardi, G. I., Teixeira, S., Neiva, J., Serrao, E. A. \& Pearson, G. A. 2013. Shift happens: trailing edge contraction associated with recent warming trends threatens a distinct genetic lineage in the marine macroalga Fucucs vesiculosus. BMC Biol. 11:6.

Oliver, E. C. J., Donat, M. G., Burrows, M. T., Moore, P. J., Smale, D. A., Alexander, L. V., Benthuysen, J. A. et al. 2018. Longer and more frequent marine heatwaves over the past century. Nat. Commun. 9:1324.

Parmesan, C., Ryrholm, N., Stefanescu, C., Hill, J. K., Thomas, C. D., Descimon, H., Huntley, B. et al. 1999. Polward shifts in geographical ranges of butterfly species associated with regional warming. Nature 399:579-83.

Pearce, A. F. \& Feng, M. 2013. The rise and fall of the "marine heat wave" off Western Australia during the summer of 2010/2011. J. Mar. Syst. 111:139-56.

Pearson, G. A., Lago-Leston, A. \& Mota, C. 2009. Frayed at the edges: selective pressure and adaptive response to abiotic stressors are mismatched in low diversity edge populations. $J$. Ecol. 97:450-62.

Perkins, S. E., Alexander, L. V. \& Nairn, J. R. 2012. Increasing frequency, intensity and duration of observed global heatwaves and warm spells. Geophys. Res. Lett. 39:1-5.

Pessarrodona, A., Moore, P. J., Sayer, M. D. J. \& Smale, D. A. 2018. Carbon assimilation and transfer through kelp forests in the NE Atlantic is diminished under a warmer ocean climate. Glob. Change Biol. 24:4386-98.

Poloczanska, E. S., Brown, C. J., Sydeman, W. J., Kiessling, W., Schoeman, D. S., Moore, P. J., Brander, K. et al. 2013. Global imprint of climate change on marine life. Nat. Clim. Chang. 3:919-25.

Raybaud, V., Beaugrand, G., Goberville, E., Delebecq, G., Destombe, C., Valero, M., Davoult, D., Morin, P. \& Gevaert, F. 2013. Decline in kelp in West Europe and climate. PLoS ONE 8:e66044.

Reed, D. H. \& Frankham, R. 2003. Correlaton between fitness and genetic diversity. Conserv. Biol. 17:230-7.

Reed, D., Washburn, L., Rassweiler, A., Miller, R., Bell, T. \& Harrer, S. 2016. Extreme warming challenges sentinel status of kelp forests as indicators of climate change. Nat. Commun. 7:13757.

Rothäusler, E., Gómez, I., Hinojosa, I. A., Karsten, U., Tala, F. \& Thiel, M. 2009. Effect of temperature and grazing on growth and reproduction of floating Macrocystis spp. (Phaeophyceae) along a latitudinal gradient. J. Phycol. 45:547-59.

Ruthrof, K. X., Breshears, D. D., Fontaine, J. B., Froend, R. H., Matusick, G., Kala, J., Miller, B. P. et al. 2018. Subcontinental heat wave triggers terrestrial and marine, multi-taxa responses. Sci. Rep. 8:13094.

Saada, G., Nicastro, K. R., Jacinto, R., McQuaid, C. D., Serrão, E. A., Pearson, G. A. \& Zardi, G. I. 2016. Taking the heat: distinct vulnerability to thermal stress of central and threatened peripheral lineages of a marine macroalga. Divers. Distrib. 22:1060-8.

Sanford, E. \& Kelly, M. W. 2011. Local adaptation in marine invertebrates. Ann. Rev. Mar. Sci. 3:509-35.

Schaal, G., Riera, P. \& Leroux, C. 2009. Trophic significance of the kelp Laminaria digitata (Lamour.) for the associated food web: a between-sites comparison. Estuar. Coast. Shelf Sci. 85:565-72. 
Schonbeck, M. \& Norton, T. A. 1978. Factors controlling the upper limits of fucoid algae on the shore. J. Exp. Mar. Bio. Ecol. 31:303-13.

Schultze, K., Janke, K., Krüß, A. \& Weidemann, W. 1990. The macrofauna and macroflora associated with Laminaria digitata and $L$. hyperborea at the island of Helgoland (German Bight, North Sea). Bot. Mar. 44:39-51.

Smale, D. A., Burrows, M. T., Moore, P., O'Connor, N. \& Hawkins, S. J. 2013. Threats and knowledge gaps for ecosystem services provided by kelp forests: a northeast Atlantic perspective. Ecol. Evol. 3:4016-38.

Smale, D. A. \& Wernberg, T. 2013. Extreme climatic event drives range contraction of a habitat-forming species. Proc. R. Soc. B Biol. Sci. 280:20122829.

Smale, D. A., Wernberg, T., Oliver, E. C. J., Thomsen, M. S., Harvey, B. P., Straub, S., Burrows, M. T. et al. 2019. Marine heatwaves threaten global biodiversity and the provision of ecosystem services. Nat. Clim. Change 9:306-12.

Smyth, T. J., Fishwick, J. R., Al-Moosawi, L., Cummings, D. G., Harris, C., Kitidis, V., Rees, A., Martinez-Vicente, V. \& Woodward, E. M. S. 2010. A broad spatio-temporal view of the Western English Channel observatory. J. Plankton Res. 32:585-601.

Steneck, R. S., Graham, M. H., Bourque, B. J., Corbett, D., Erlandson, J. M., Estes, J. A. \& Tegner, M. J. 2002. Kelp forest ecosystems: biodiversity, stability, resilience and future. Environ. Conserv. 29:436-59.
Sunday, J. M., Bates, A. E. \& Dulvy, N. K. 2012. Thermal tolerance and the global redistribution of animals. Nat. Clim. Change 2:86-90.

Thomson, J. A., Burkholder, D. A., Heithaus, M. R., Fourqurean, J. W., Fraser, M. W., Statton, J. \& Kendrick, G. A. 2015. Extreme temperatures, foundation species, and abrupt ecosystem change: an example from an iconic seagrass ecosystem. Glob. Change Biol. 21:1463-74.

Valladares, F., Matesanz, S., Guilhaumon, F., Araújo, M. B., Balaguer, L., Benito-Garzón, M., Cornwell, W. et al. 2014. The effects of phenotypic plasticity and local adaptation on forecasts of species range shifts under climate change. Ecol. Lett. 17:1351-64.

Van Peer, L., Nijs, I., Reheul, D. \& De Cauwer, B. 2004. Species richness and susceptibility to heat and drought extremes in synthesized grassland ecosystems: compositional vs physiological effects. Funct. Ecol. 18:769-78.

Viejo, R. M., Martínez, B., Arrontes, J., Astudillo, C. \& Hernández, L. 2011. Reproductive patterns in central and marginal populations of a large brown seaweed: Drastic changes at the southern range limit. Ecography (Cop.) 34:75-84.

Wernberg, T., Bennett, S., Babcock, R. C., Bettignies, T. De, Cure, K., Depczynski, M., Dufois, F. et al. 2016. Climate-driven regime shift of a temperate marine ecosystem. Science 353:169-72.

Wernberg, T., Smale, D. A., Tuya, F., Thomsen, M. S., Langlois, T. J., de Bettignies, T., Bennett, S. \& Rousseaux, C. S. 2013. An extreme climatic event alters marine ecosystem structure in a global biodiversity hotspot. Nat. Clim. Change 3:78-82. 